\title{
pH Assist for Highly selective determination of Xipamide by the enhancement of the green emission of Tb3+ optical sensor
}

\author{
M. S. Attia, A. O. Yuossef, M. Diab, M. F. El-Shahat
}

Chemistry Department, Faculty of Science, Ain Shams University, Abbassia, Cairo, Egypt

\section{Abstract}

The highly selective, accurate method for determination of Xipamide was maintained. The method depends on the enhancement of the green emission band of $\mathrm{Tb}^{3+}$ at $545 \mathrm{~nm}$ in the presence of different concentration of Xipamide at $\mathrm{pH} 4.1$ and $\lambda_{\mathrm{ex}}=320 \mathrm{~nm}$ in acetonitrile. The photophysical properties of the green emissive $\mathrm{Tb}^{3+}$ complex have been elucidated, the terbium was used as optical sensor for the assessment of Xipamide in the pharmaceutical tablets and body fluids with a concentration range $5.0 \times 10^{-9}-2.3 \times 10^{-6} \mathrm{~mol} \mathrm{~L}^{-1}$ of xipamide, correlation coefficient of 0.995 and detection limit of $8.5 \times 10^{-10} \mathrm{~mol} \mathrm{~L}^{-1}$.

Keywords: Xipamide; Terbium(III); Enhancing; Luminescence; Optical sensor.

Corresponding author: Mohamed_sam@yahoo.com

Tel: +202 44678582

Mobile: 01229867311

\section{Council for Innovative Research}

Peer Review Research Publishing System

Journal: Journal of Advances in Chemistry

Vol. 10, No. 5

editorjaconline@gmail.com

www.cirjac.com 


\section{Introduction}

Xipamide, N-(2,6-dimethylphenyl)sulphamido-5-chloro-4-salicylamide Fig. 1. It is a new diuretic drug. Thiazide and thiazide-like diuretics are extremely useful in the treatment of edema associated with heart failure, cirrhosis of the liver or nephritic syndrome. These diuretics are primary agents in the control of hypertension either alone or in combination with other drugs depending on its severity. Generally, thiazide and thiazide-like diuretics decrease blood pressure 10 to 15 $\mathrm{mmHg}$ within the first 3 to 4 days of continuous treatment [1]. Several methods have been published for determination of these drugs. These methods include spectrophotometry [2-12], fluorometry [7], chromatography [12-22], electrophoresis [23-29] and electrochemical methods [30-34]. Voltammetric, chromatographic and electrophoretic methods usually used expensive instruments that may not be available in some quality control laboratories. In this work, xipamide (Xip) concentration was determined by the complexation between (Xip) as a ligand and the $\mathrm{Tb}^{3+}$ ion and the possibility of the enhancement of the $\mathrm{Tb}^{3+}$ luminescence sensitized by (Xip) was established and investigated. The absorption and emission spectra of $(\mathrm{Xip})$ and $\left(\mathrm{Xip}-\mathrm{Tb}^{3+}\right)$ complex were measured in acetonitrile at $\mathrm{pH}$ 4.1. This method is simple, accurate and can successfully be applied to the determination of (Xip) in pharmaceutical preparation and in serum samples with remarkably satisfactory results.

\section{Experimental}

\subsection{Materials}

Pure standard xipamide supplied by the National organization for Drug control and Research (Giza, Egypt). Pharmaceutical preparation of Epitens ${ }^{\circledR}$ tablets (Egyptian Pharmaceutical Industries Co., [EIPICO] Tenth of Ramadan city, Egypt) labeled to contain $10 \mathrm{mg}$ of xipamide.

\subsection{Reagents}

All chemicals used are of analytical grade and pure solvents were purchased from (Aldrich). A stock solution of xipamide (Xip) $\left(1.0 \times 10^{-2} \mathrm{~mol} \mathrm{~L}^{-1}\right)$ was freshly prepared by dissolving $0.093 \mathrm{~g}$ in $25 \mathrm{~mL}$ pure ethanol. More diluted solution $\left(1.0 \times 10^{-4} \mathrm{~mol} \mathrm{~L}^{-1}\right)$ was prepared by appropriate dilution with acetonitrile. Stock and working solutions are stored at $4^{\circ} \mathrm{C}$ when are not in use.

A $\mathrm{Tb}^{3+}$ ion stock solution $\left(1.0 \times 10^{-2} \mathrm{~mol} \mathrm{~L}^{-1}\right)$ was prepared by dissolving $0.0109 \mathrm{~g} \mathrm{~Tb}\left(\mathrm{NO}_{3}\right)_{3} .5 \mathrm{H}_{2} \mathrm{O}$ (delivered from Aldrich- 99.99\%) in small amount of ethanol in $25 \mathrm{~mL}$ measuring flask, then dilute to the mark with ethanol. The working solution of $\mathrm{Tb}^{3+}$ ion of $3 \times 10^{-4} \mathrm{~mol} \mathrm{~L}^{-1}$ was obtained by appropriate dilution with acetonitrile. The $\mathrm{pH}=4.1$ was adjusted by using $0.1 \mathrm{~mol} \mathrm{~L}^{-1}$ of Acetic acid solution.

\subsection{Apparatus}

All fluorescence measurements are carried out on Perkin Elmer LS 45 spectrofluorophotometer in the range (290 - $750 \mathrm{~nm}$ with attenuator 30\%). The absorption spectra are recorded with Thremo UV-Visible double-beam spectrophotometer. All pH measurements are made with a pHs-JAN-WAY 3040 ion analyzer.

\subsection{General procedure}

To $10 \mathrm{~mL}$ measuring flasks, solutions were added in the following order: $0.1 \mathrm{~mL}$ of $1 \times 10^{-2} \mathrm{~mol} \mathrm{~L}^{-1}$ XIP solution and $0.3 \mathrm{~mL}$ of $1 \times 10^{-2} \mathrm{~mol} \mathrm{~L}^{-1} \mathrm{~Tb}^{3+}$ solution to give $1 \times 10^{-4} \mathrm{~mol} \mathrm{~L}^{-1}$ of XIP and $3 \times 10^{-4} \mathrm{~mol} \mathrm{~L}^{-1}$ of Tb $\mathrm{Tb}^{3+}$. The mixture was diluted to the mark with acetonitrile and $\mathrm{pH}$ was adjusted at 4.1 by using $0.1 \mathrm{~mol} \mathrm{~L}^{-1}$ of Acetic acid solution. The above procedure was used for the subsequent measurements of absorption, emission spectra and effect of $\mathrm{pH}$ and solvents. The luminescence intensity was measured at $\lambda_{\mathrm{ex}} / \lambda_{\mathrm{em}}=320 / 545 \mathrm{~nm}$.

\subsection{Determination of xipamide in pharmaceutical preparations}

Five tablets of Epitens $\AA^{\circledR}$ were carefully weighed and ground to finely divided powders. Accurate weights equivalent to $1.5 \mathrm{mg}$ Epitens $\AA$ was dissolved in $50 \mathrm{~mL}$ acetonitrile and mixed well and filtered up using $12 \mathrm{~mm}$ filter paper. The concentration of the drug was determined by using different concentrations from the corresponding calibration graph.

\subsection{Determination of xipamide in serum solution}

$3 \mathrm{~mL}$ of trichloroacetic acid was added to $1.0 \mathrm{~mL}$ serum of a real health volunteer and the solution was centrifuged for $15 \mathrm{~min}$ at $4000 \mathrm{r} / \mathrm{min}$ to remove proteins, then $100 \mu \mathrm{L}$ of the serum was added to $0.3 \mathrm{~mL}$ of $\mathrm{Tb}^{3+}$ stock solution $\left(1 \times 10^{-2} \mathrm{~mol} \mathrm{~L}^{-1}\right)$ in $10 \mathrm{~mL}$ measuring flask and complete to the mark with acetonitrile and the $\mathrm{pH}$ was adjusted to

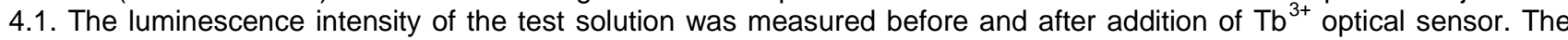
change in the luminescence intensity was used for determination of xipamide in serum sample.

\subsection{Determination of xipamide in urine solution}

Urine sample of healthy people was collected from volunteer who received a single oral dose of $10 \mathrm{mg}$ of Epitens $\AA$ tablet. The treatment procedure of used urine sample was carried out according to the method described by N.A. Al-Arfaj [35]. $1.0 \mathrm{~mL}$ urine sample was pipetted into clean $10 \mathrm{~mL}$ centrifugation vial. $0.1 \mathrm{~mL}$ of $0.1 \mathrm{~mol} / \mathrm{L} \mathrm{NaOH}$ solution was added, shaken for few seconds, followed by the addition of $5 \mathrm{~mL}$ dichloromethane. The mixture was vortex mixed at high speed for $2 \mathrm{~min}$ and then centrifuged at $4000 \mathrm{rpm}$ for $10 \mathrm{~min}$. The resulting supernatant was transferred to a 
small conical flask. The extract was evaporated to dryness at $60{ }^{\circ} \mathrm{C}$ and the residue was dissolved in $0.5 \mathrm{~mL}$ water and then analyzed according to the proposed procedure

\section{Result and Discussion}

\section{1. Absorption and Emission Spectra}

The absorption spectra of XIP and $\mathrm{Tb}^{3+}$ - XIP complex are shown in Fig. 2. Comparing the spectrum of the XIP with its spectra after the addition of different concentrations of $\mathrm{Tb}^{3+}$ ion in acetonitrile, a red shift was observed and the absorbance is also enhanced which indicates that XIP can form a complex with $\mathrm{Tb}^{3+}$ ion.

The emission spectra of $\mathrm{Tb}^{3+}-$ XIP complex in different concentrations of XIP are shown in Fig. 3. After the addition of different concentrations of XIP into the $\mathrm{Tb}^{3+}$ ion in acetonitrile, the intensity of the characteristic peak at $545 \mathrm{~nm}^{3}$ of $\mathrm{Tb}^{3+}$ was enhanced indicating that XIP can form a complex with $\mathrm{Tb}^{3+}$ ion. The characteristic peaks of $\mathrm{Tb}^{3+}$ ion appear at $\left({ }^{5} \mathrm{D}_{4} \rightarrow\right.$ ${ }^{7} \mathrm{~F}_{6}=490 \mathrm{~nm},{ }^{5} \mathrm{D}_{4} \rightarrow{ }^{7} \mathrm{~F}_{5}=545 \mathrm{~nm},{ }^{5} \mathrm{D}_{4} \rightarrow{ }^{7} \mathrm{~F}_{4}=590 \mathrm{~nm},{ }^{5} \mathrm{D}_{4} \rightarrow{ }^{7} \mathrm{~F}_{3}=620 \mathrm{~nm}$ and $\left.{ }^{5} \mathrm{D}_{4} \rightarrow{ }^{7} \mathrm{~F}_{2}=650 \mathrm{~nm}\right)$.

\subsection{Effect of experimental variables}

\subsubsection{Effect of the amount of XIP and $\mathrm{Tb}^{3+}$}

The ion titration revealed that the complex formed $M: L(3: 1)$ for Tb and XIP, which indicates that the metal may coordinate to the ligand from different coordination sites and not only through oxygen of the ketone ring, but the more preferred coordination sites are the $\mathrm{O}$ of the ketone group and the nitrogen of the amide ring because they have the highest negative charges, Fig. 4.

\subsubsection{Effect of $\mathrm{pH}$}

The $\mathrm{pH}$ of the medium has a great effect on the luminescence intensity of the Tb-XIP. The $\mathrm{pH}$ has been adjusted using Acetic acid solution. The optimum pH value where the peak at $545 \mathrm{~nm}$ has the highest intensity was obtained at $\mathrm{pH}$ $=4.1$, Fig. 5 .

\subsubsection{Effect of solvent}

The influence of the solvent on the luminescence intensities of the solutions containing $1.0 \times 10^{-4} \mathrm{~mol}$ $\mathrm{L}^{-1}$ of XIP and $3.0 \times 10^{-4} \mathrm{~mol} \mathrm{~L}^{-1} \mathrm{~Tb}^{3+}$ was studied under the conditions established above. The results show the enhanced emission of $\mathrm{Tb}^{3+}-\mathrm{XIP}$ in $\mathrm{CH}_{3} \mathrm{CN}$. This can be attributed to the formation of anhydrous solvates of $\mathrm{Tb}^{3+}$-XIP complex introducing solvent molecules in the first coordination sphere of $\mathrm{Tb}^{3+}-\mathrm{XIP}$ leads to the enhancement of the intensity of all transitions $\left({ }^{5} D_{4} \rightarrow{ }^{7} F_{6}=490 \mathrm{~nm},{ }^{5} D_{4} \rightarrow{ }^{7} F_{5}=545 n m,{ }^{5} D_{4} \rightarrow{ }^{7} F_{4}=590\right.$ $\mathrm{nm},{ }^{5} \mathrm{D}_{4} \rightarrow{ }^{7} \mathrm{~F}_{3}=620 \mathrm{~nm}$ and $\left.{ }^{5} \mathrm{D}_{4} \rightarrow{ }^{7} \mathrm{~F}_{2}=650 \mathrm{~nm}\right)$. especially ${ }^{5} \mathrm{D}_{4} \rightarrow{ }^{7} \mathrm{~F}_{5}$ transition in $\mathrm{Tb}^{3+}$.

\subsection{Analytical performance}

\subsubsection{Method Validation}

\subsubsection{Analytical parameters of optical sensor method}

A linear correlation was found between luminescence intensity of XIP- $\mathrm{Tb}^{3+}$ complex at $\lambda_{\mathrm{em}}=545 \mathrm{~nm}$ and concentration of XIP in the ranges given in Table 1. The calibration curve was obtained by plotting the peak intensity of $\mathrm{Tb}^{3+}$ at $\lambda_{\mathrm{em}}=545 \mathrm{~nm}$ versus the concentration of XIP and the graph was described by the regression equation:

$$
Y=a+b X
$$

(Where $Y=$ luminescence intensity of the optical sensor at $\lambda_{\mathrm{em}}=545 \mathrm{~nm}$; $a=$ intercept; $b=$ slope and $X=$ concentration in $\mathrm{nmol} \mathrm{mL}{ }^{-1}$ ). Regression analysis of luminescence intensity data using the method of least squares was made to evaluate the slope (b), intercept (a) and correlation coefficient $(r)$ and the values were presented in Table 1. The limit of detection (LOD) and quantitation (LOQ) calculated according to ICH guidelines [36] using the formulae:

$L O D=3.3 \mathrm{~S} / \mathrm{b}$ and $\mathrm{LOQ}=10 \mathrm{~S} / \mathrm{b}$, (where $\mathrm{S}$ is the standard deviation of blank luminescence intensity values, and $\mathrm{b}$ is the slope of the calibration plot) are also presented in Table 1. The low value of LOD indicates the high sensitivity of the proposed method when compared by other methods [2-34]

\subsubsection{Application to formulations}

The proposed method was applied to the determination of XIP in one representative tablet of Epitens ${ }^{\circledR}$ was purchased from local market and containing other inactive ingredients and in serum sample of the health state human. The results in Table 2 show that the method is successful for the determination of XIP and that the excipients in the dosage forms did not interfere. The results obtained (Table 2) were statistically compared with the official British Pharmacopoeia [B.P] method [37]. The average recovery and R.S.D for the tablet, serum and urine sample in proposed method were $(100.2 \%, 99.6$ and $104.1 \%)$ respectively. Data obtained by B. P method average recovery $99.5 \%$, 99.8 and 98.8 for the tablet, serum and urine samples respectively; and R.S.D was also presented for comparison and shows a good correlation with those obtained by the proposed method. The results obtained by the proposed method agreed well with those of reference method and with the label claim (Table 2). 


\section{Conclusion}

The $\mathrm{Tb}^{3+}$ ion in acetonitrile has high sensitive and characteristic peaks in the presence of XIP. The proposed method for the determination of XIP offers simple, rapid and sensitive method for the analysis of $\mathrm{XIP}$ in acetonitrile and $\mathrm{pH} 4.1$ with a linear range of $5.0 \times 10^{-9}-2.3 \times 10^{-6} \mathrm{~mol} \mathrm{~L}^{-1}$ and detection limit of $8.5 \mathrm{x}$ $10^{-10} \mathrm{~mol} \mathrm{~L}^{-1}$. The developed optical sensor is selective, accurate and attractive for routine control analysis of the drug.

\section{References}

1 B N. C Prlchard and R N Brogden, Drugs, 30 (1985) 313

2 C Nazaret, J Dlez, P A Hannaert, M 0 Christen, N. Wlerzbickl and R P Garay. Eur J Pharmacol, 114 (1987) 352

3 P Hannaert, E Jeanclos, M 0 Chrlsten, N Wlerzblckl and R Garay, Arch Mal Coeur Vam, 81(1988) 15-9

4 P Lqnen and A Amery, Methods Fmd E.Y Clm, Pharmacol , 11 (1989) 587.

5. Bedair MM, Korany MA, Ebdel-Hay MA, Gazy AA (1990)

Analyst 115(4):449-453

6. Panderi I, Parissi-Poulou M (1994) J Pharm Biomed Anal 12

(2):151-156

7. Ferraro MC, Castellano PM, Kaufman TS (2002) J Pharm Biomed Anal 30(4):1121-1131

8. Dince E, Baleanu D (2002) J Pharm Biomed Anal 30(3):715-723

9. Albero I, Rodenos V, Garcia S, Sanchez-Pedreno C (2002) J

Pharm Biomed Anal 29(1-2):299-305

10. Youssef NF (2003) J AOAC Int 86(5):935-940

11. Agrawal YK, Majumdar FD (1995) Anal Lett 28(9):16191627

12. Sastry CSP, Suryanarayana MV, Tipirneni ASRP (1989) Indian Drugs 26(6):304-306

13. Sastry CSP, Suryanarayana MV, Tipirneni ASRP (1989) Talanta 36(4):491-494

14. El-Kommos ME, Ahmad A, Salem H, Omar MA (2006) Bull Pharm Sci 29(1):33-58

15. Garg G, Saraf S, Saraf S (2008) J AOAC Int 91(5):1045-1050

16. Brown SM, Busch KL (1991) J PlanarChromatogr Mod TLC 4

(3):189-193

17. Carda-Broch S, Esteve-Romero JS, Garcia-Alvarez-Coque MC

(1998) Anal Chem Acta 375(1-2):143-154

18. Frontini R, Mielck JBJ (1992) Liq Chromatogr 15(14):2519-

2528

19. Torres-Lapasio JR, Baeza-Baeza JJ, Garcia-Alvarez-Coque MC

(1997) J Chromatogr A 769(2):155-168

20. Dadgar D, Kelly M (1988) Analyst 113(2):229-231

21. Deventer K, Pozo OJ, Van Eenoo P, Delbeke FT (2009) J

Chromatogr A 20(12):2466-2473

22. Sultana N, Arayne MS, Ali SS, Sajid S (2008) Se Pu 26(5):

544-549 
23. Obando MA, Estela JM, Cerdà V (2008) Anal Bioanal Chem

391(6):2349-2356

24. Rane VP, Sangshetti JN, Shinde DB (2008) J Chromatogr Sci

46(10):887-891

25. Yan T, Li H, Deng L, Guo Y, Yu W, Fawcett JP, Zhang D, Cui Y,

Gu J (2008) J Pharm Biomed Anal 48(4):1225-1229

26. Gonzalez E, Becerra A, Laserna JJ (1996) J Chromatogr B

Biomed-Appl 687(1):145-150

27. Quaglia MG, Donati E, Carlucci G, Mazzeo P, Fanali S (2002) J

Pharm Biomed Anal 29(6):981-987

28. Gonzalez E, Montes R, Laserna J (1993) J Anal Chem Acta

282(2):687-693

29. Zheng X, Lu M, Zhang L, Chi Y, Zheng L, Chen G (2008) Talanta

76(1):15-20

30. Liu X, Song Y, Yue Y, Zhang J, Chen X (2008) Electrophoresis

29(13):2876-2883

31. Sirén H, Shimmo R, Sipola P, Abenet S, Riekkola ML (2008) J

Chromatogr A 1198-1199:215-219

32. Zhou N, Liang YZ, Wang B, Wang P, Chen X, Zeng MM (2008)

Biomed Chromatogr 22(3):223-231

33. Mohamed ME, Aboul-Enein HY (1985) Anal Lett 18(20):

2591-2603

34. Legorburu MJ, Alonso RM, Jimenez RM (1993) Bioelectrochem-

Bioenerg 32(1):57-66

35. N.A. Al-Arfaj,Flow-injection chemiluminescent determination of metoclopramide hydrochloride in pharmaceutical formulations and biological fluids using the [Ru(dipy)2+]-permanganate system, Talanta 62 (2004) 255-263.

36. International Conference on Hormonisation of Technical Requirements for Registration of Pharmaceuticals for Human Use, ICH Harmonised Tripartite Guideline, Validation of Analytical Procedures: Text and Methodology Q2(R1), Complementary Gui deline on Methodology dated 06 November 1996, incorporated in November 2005, London.

37. British Pharmacopoeia, (1999). Vol. II, Her Majesty's Stationary Office, London, p. 2705.

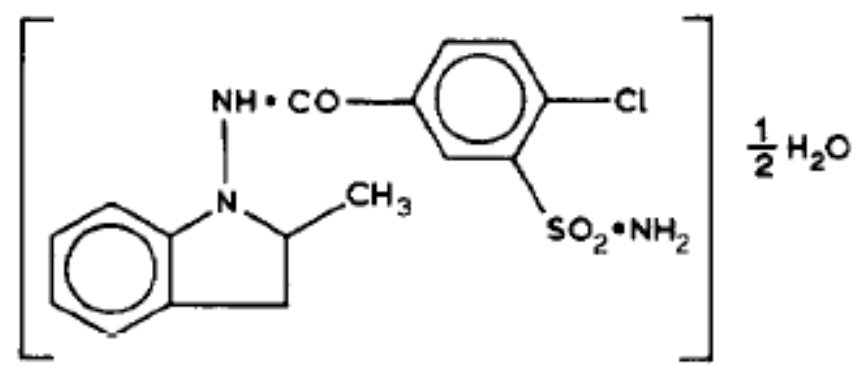

Fig. 1. Chemical structure of xipamide 


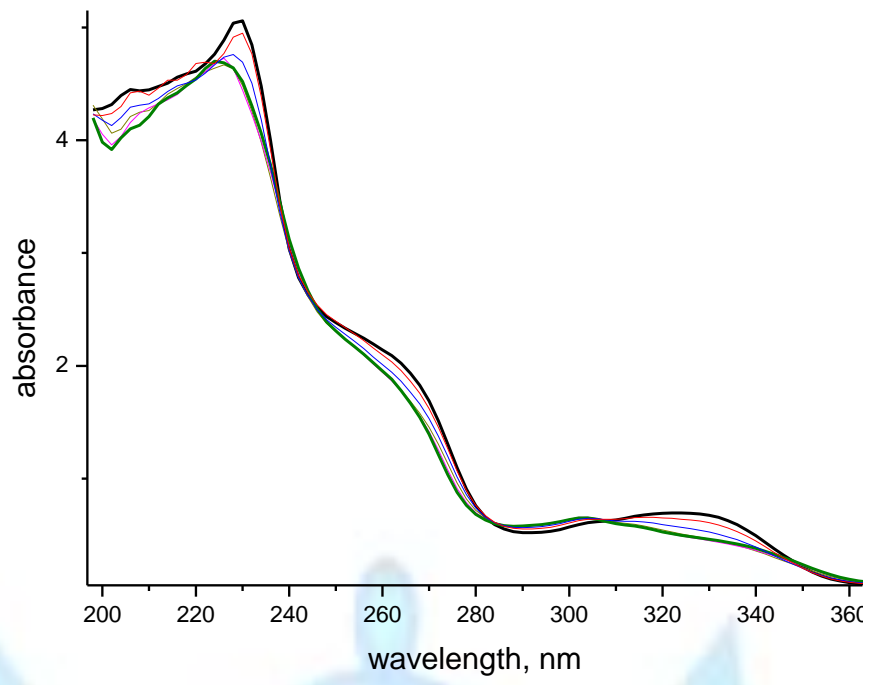

Fig. (2). Absorption spectra of $1 \times 10^{-4} \mathrm{~mol} / \mathrm{L}$ xipamide (1) and xipamide in different concentrations of $\mathrm{Tb}^{3+}$ ion (26).

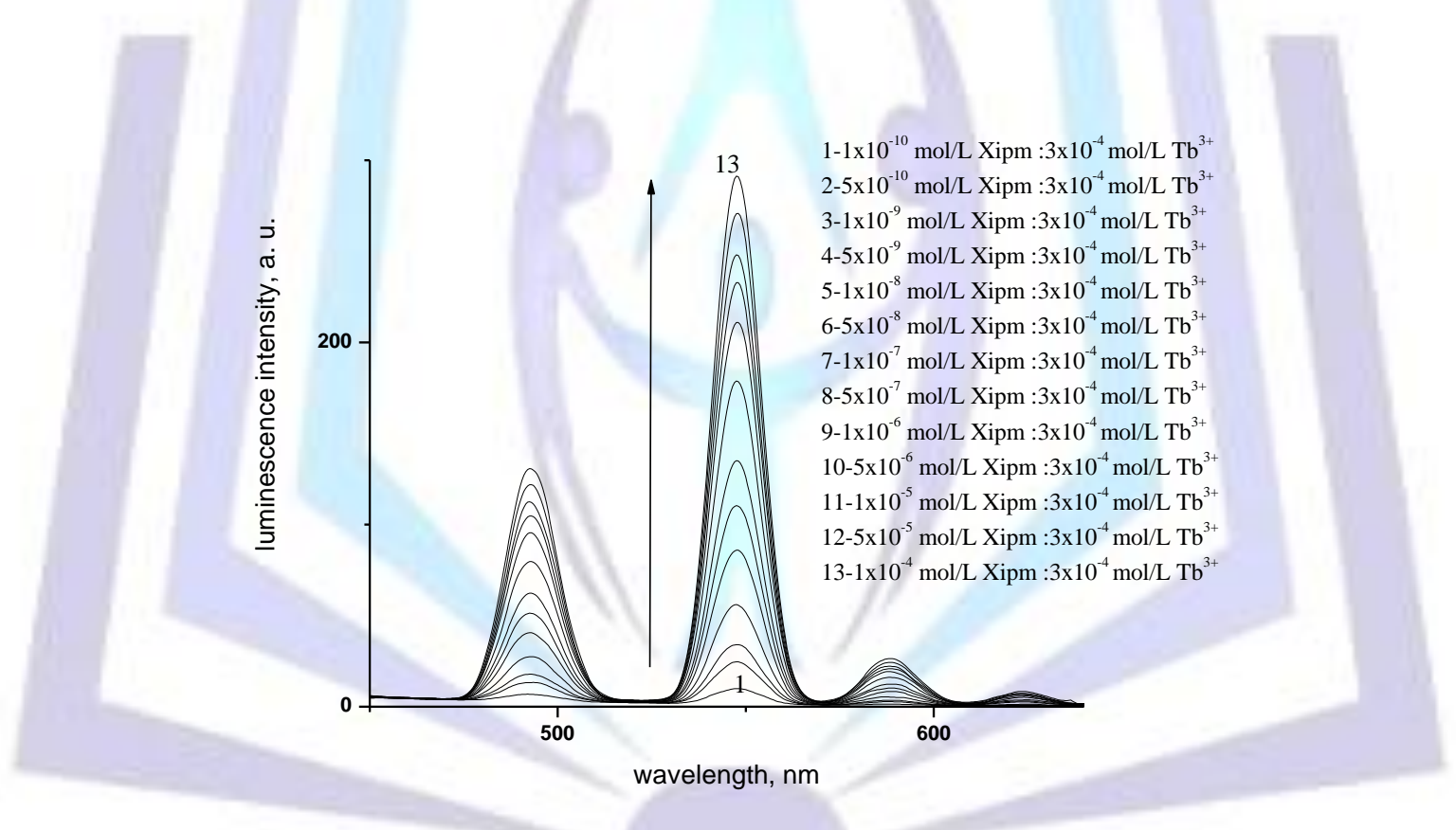

Fig. (3). Luminescence emission spectra of $3 \times 10^{-4} \mathrm{~mol} / \mathrm{L} \mathrm{Tb}{ }^{3+}$ in different concentrations of xipamide at $\mathrm{pH} 4.1$ and $\lambda_{\mathrm{ex}}=320 \mathrm{~nm}$ in acetonitrile. 


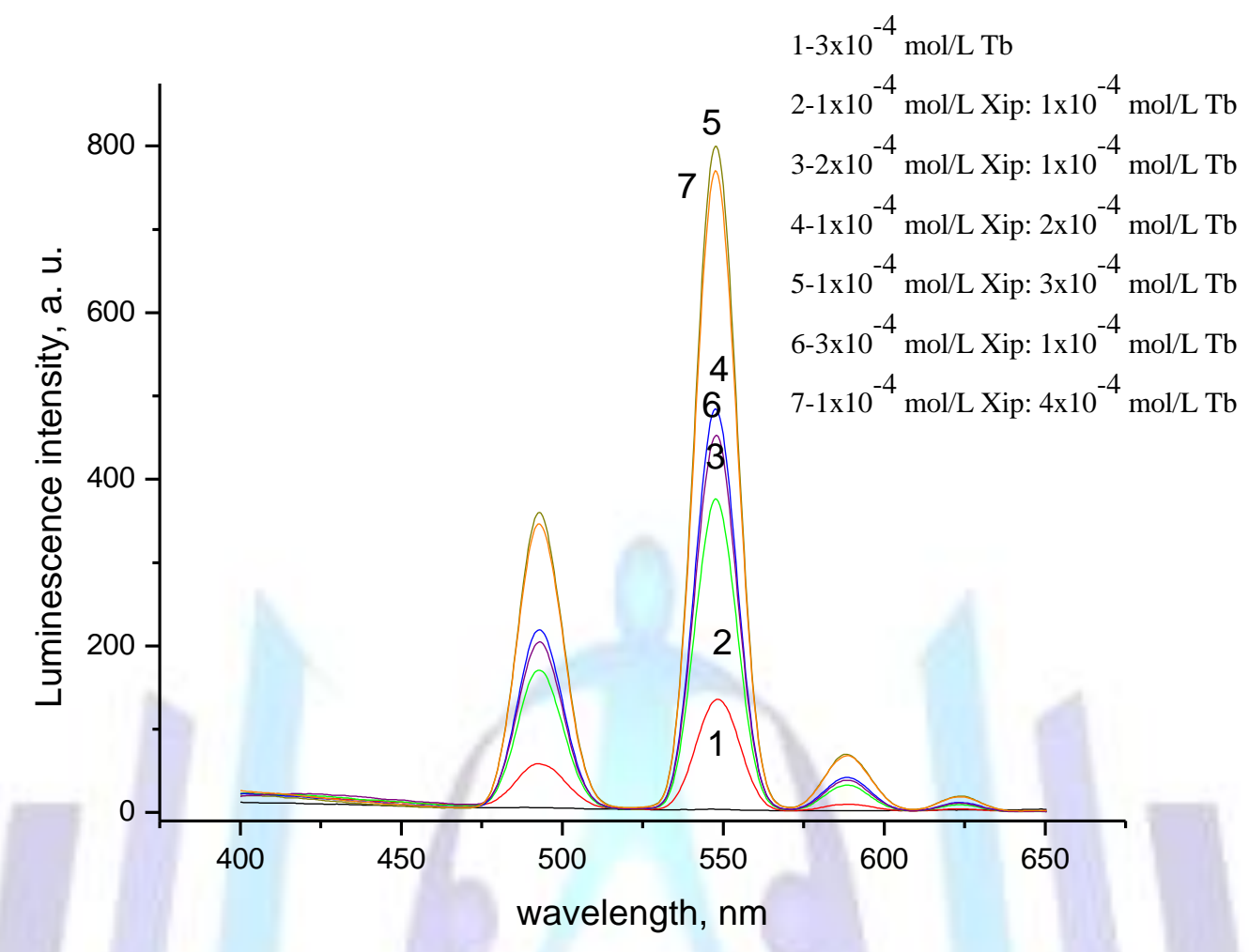

Fig. (4). Luminescence emission spectra of $3 \times 10^{-4} \mathrm{~mol} / \mathrm{L} \mathrm{Tb^{3+ }}$ in different molar ratio of xipamide.

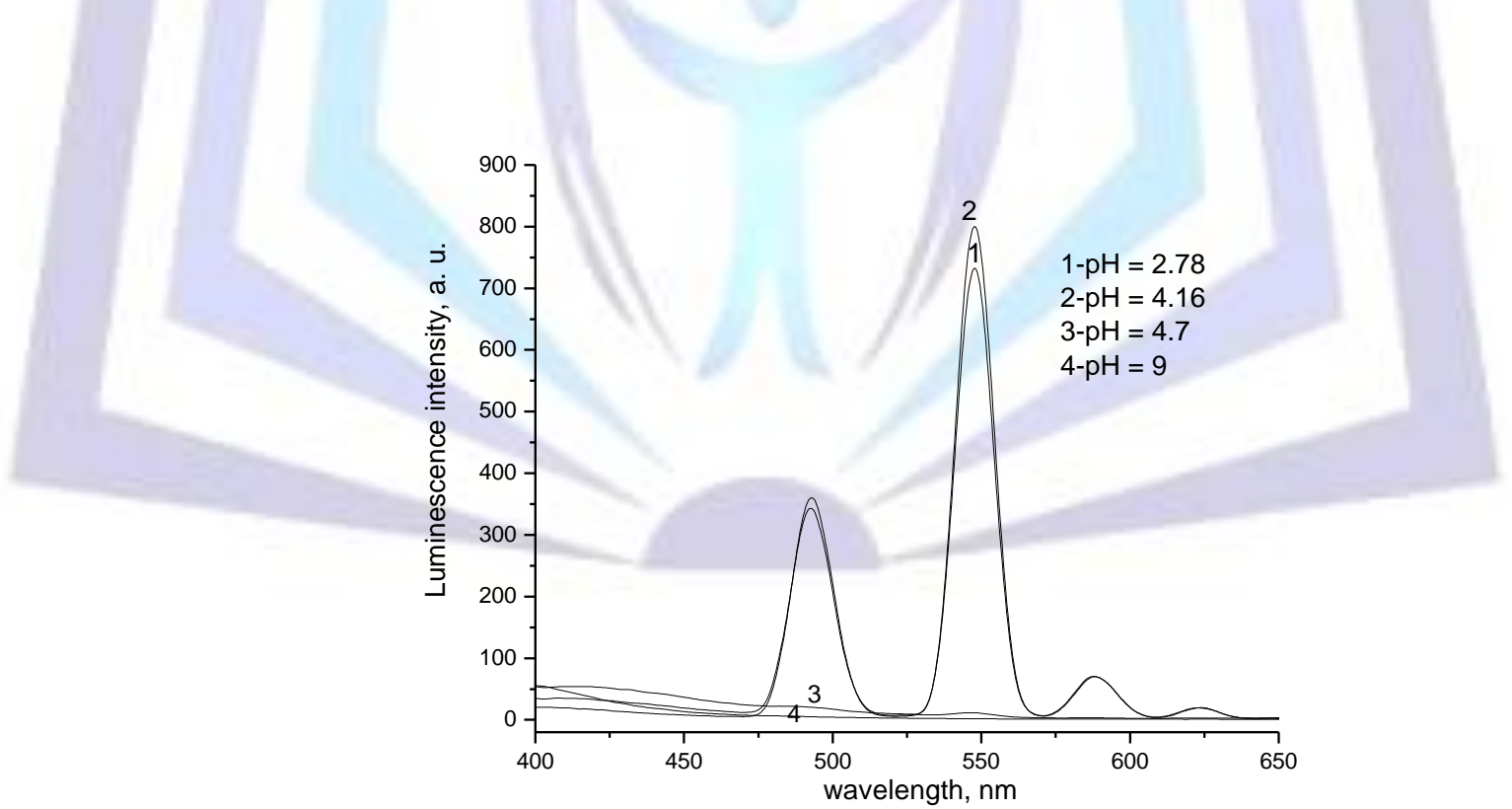

Fig.(5) . Luminescence emission spectra of $3 \times 10^{-4} \mathrm{~mol} / \mathrm{L} \mathrm{Tb}^{3+}$ in the presence of $1 \times 10^{-4} \mathrm{~mol} / \mathrm{L}$ xipamide in acetonitrile and $\lambda_{\mathrm{ex}}=320 \mathrm{~nm}$ in different $\mathrm{pH}$. 
Tables:

Table (1): Sensitivity and regression parameters for the proposed method.

\begin{tabular}{|c|c|}
\hline Parameter & \\
\hline$\lambda_{\mathrm{em}} \mathrm{nm}$ & 545 \\
\hline Linear range, $\mathrm{mol} \mathrm{L}^{-1}$ & $5 \times 10^{19}-2.3 \times 10^{-6}$ \\
\hline Limit of detection (LOD), $\mathrm{mol} \mathrm{L}^{-1}$ & $8.5 \times 10^{-10}$ \\
\hline Limit of quantification (LOQ), $\mathrm{mol} \mathrm{L}^{-1}$ & $2.5 \times 10^{-9}$ \\
\hline Intercept a & 9.9 \\
\hline Slope b & $2.2 \times 10^{8}$ \\
\hline Standard deviation & 0.07 \\
\hline Variance & 0.049 \\
\hline Regression coefficient & 0.995 \\
\hline
\end{tabular}

Table 2. Results of recovery study using standard addition method

\begin{tabular}{|c|c|c|c|c|}
\hline \multicolumn{5}{|c|}{ Proposed method } \\
\hline $\begin{array}{c}\text { Tablet } \\
\text { studied }\end{array}$ & $\begin{array}{c}\text { Xipamide in } \\
\text { Tablet extract X } 10^{-} \\
\text {mol L L }^{-1}\end{array}$ & $\begin{array}{c}\text { Pure Xipamide } \\
\text { added } \times 10^{-7} \text { mol } \\
L^{1}\end{array}$ & $\begin{array}{l}\text { Total Xipamide } \\
\text { found } \times 10^{-7} \text { mol } \\
L^{-1}\end{array}$ & $\begin{array}{l}\text { Pure Xipamide recovered } \\
\text { (Percent } \pm S D)\end{array}$ \\
\hline \multirow{3}{*}{ Tablet } & 10 & 1.0 & 10.40 & $0.48 \pm 99.10$ \\
\hline & 1.0 & 4.0 & 4.95 & $0.42 \pm 98.75$ \\
\hline & 0.1 & 2.5 & 2.65 & $0.73 \pm 101.09$ \\
\hline \multirow{3}{*}{$\begin{array}{l}\text { Urine } \\
\text { sample }\end{array}$} & 10 & 1.0 & 11.38 & $0.61 \pm 98.96$ \\
\hline & 1.0 & 4.0 & 5.15 & $0.91 \pm 103.75$ \\
\hline & 0.1 & 2.5 & 2.43 & $0.75 \pm 96.3$ \\
\hline \multirow{3}{*}{$\begin{array}{l}\text { Serum } \\
\text { sample }\end{array}$} & 10 & 1.5 & 11.46 & $1.25 \pm 99.7$ \\
\hline & 1.0 & 4.0 & 4.92 & $0.25 \pm 98.0$ \\
\hline & 0.1 & 2.5 & 2.61 & $0.85 \pm 100.2$ \\
\hline
\end{tabular}

